\title{
ANALISIS KEUNTUNGAN DAN SENSITIVITAS USAHATANI CABAI DI KABUPATEN MAROS
}

\author{
Eka Triana Yuniarsih dan Wardah Halil \\ Balai Pengkajian Teknologi Pertanian (BPTP) Sulawesi Selatan \\ Jl. Perintis Kemerdekaan Km. 17.5, Sudiang, Makassar \\ e-mail: ekatriana.yuniarsih@gmail.com
}

Received: 24 Agustus 2020; Accepted: 29 September 2020; Published: 25 Desember 2020

\begin{abstract}
ABSTRAK
Salah satu pengembangan komoditi cabai di Sulawesi Selatan adalah Kab. Maros, dengan kontribusi luas panen cabai mencapai 583 ha. Tujuan penelitian adalah mengetahui keuntungan dan sensitivitas usahatani cabai di Kab. Maros. Penelitian dilakukan di Kecamatan Tanralili, Kabupaten Maros, Sulawesi Selatan pada bulan Februari sampai Juni 2017. Data primer yang dikumpulan dari petani cabai sebanyak 60 responden dengan menggunakan kuisioner terstruktur. Data yang terkumpul dianalisis secara deskriptif tabulatif. Analisis finansial dilakukan untuk mengetahui keuntungan usahatani cabai, titik impas dan Analisis senstivitas dengan 3 skenario: barga produksi turun $30 \%$, biaya naik 30\%, produksi turun $30 \%$. Hasil yang diperoleh bahwa Usahatani Cabai di Kab. Maros secara financial menguntungkan sebesar Rp. 101.643.518 dengan nilai R/C 19,6. analisis BEP produksi dan BEP harga produksi dan harga minimum yang harus dicapai agar usahatani cabai tetap menguntungkan adalah $79,95 \mathrm{~kg} / \mathrm{ha}$ dan Rp. 3653/kg. Penurunan harga dan produksi serta peningkatan biaya produksi masih memberikan keuntungan walaupun cenderung menurun dan usahatani cabai tersebut dikatakan tidak peka atau sensitive terhadap penurunan harga serta produksi serta peningkatan biaya produksi.
\end{abstract}

\section{Kata Kunci : Usahatani Cabai, Keuntungan, Sensitivitas}

\section{PENDAHULUAN}

Cabai merah (Capsium Annum) termasuk salah satu komoditas hortikultura yang turut memberikan sumbangan yang berarti terhadap perekonomian nasional yakni meningkatkan pendapatan petani, sebagai bahan baku industri, memiliki peluang ekspor, dan membuka kesempatan kerja. Disamping itu cabai juga dapat berpengaruh terhadap inflasi walaupun cabai bukan makanan pokok di Indonesia, tetapi ada waktuwaktu tertentu terjadi kegagalan panen atau harihari raya tertentu harga cabai sangat mahal.

Para konsumen menginginkan karakter cabai antara lain tingkat kepedasan sesuai kebutuhan, penampilan buah yang baik, mulus, dan warna yang terang, serta bebas dari penyakit seperti antraknosa. Industri pangan, seperti saus dan pasta, sifat-sifat cabai yang diinginkan adalah mempunyai tingkat kepedasan tinggi, warna merah terang, dan buahnya harus tersedia sepanjang waktu untuk memenuhi kebutuhan industri (kontinuitas terjaga). (Rizqullah dan Syamsuddin, 2020)

Produksi cabai di tingkat nasional setiap tahun terus meningkat di dukung oleh banyak usaha di bidang industri dan komsumsi masyarakat yang terus meningkat. Produksi cabai di tingkat Nasional pada tahun 2015 sebesar 1.915.016 Ton dan pada tahun 2016 sebesar 1.961.598 Ton (meningkat sebesar 2 persen) dan pada tahun 2017 sebesar 2.359.441 ton (naik 20 persen) (BPS, 2019).

Luas panen cabai di Sulawesi Selatan 3.920 ha, dengan produksi 20.516 ton dan produktivitas 5,23 ton/ha. Terjadi kenaikan produksi dari tahun sebelumnya sebesar 4.540 ton atau 20,13\% (BPS SulSel, 2014). Selain itu Luas panen Cabe di Kab. Maros mencapai 583 ha dengan 
produksi mencapai $27.980 \mathrm{kwt} / \mathrm{ha}$ (BPS Kab. Maros, 2019). Akan tetapi melihat potensi luas areal pertanaman belum memberikan manfaat yang optimal bagi petani dan perekonomian nasional.

Permasalahan/kendala utama yang dapat menyebabkan bisnis usaha kecil budidaya cabai merah sering menghadapi risiko gagal yaitu tidak adanya kepastian jual, harga yang berfluktuasi, kemungkinan rendahnya margin usaha, lemahnya akses pasar, dan ketidakmampuan untuk memenuhi persyaratan teknis bank. Oleh karena itu upaya peningkatan produksi cabai merah dilakukan melalui ekstensifikasi dan intensifikasi.

Umumnya petani yang menjalankan usahatani cabai merah ini jarang sekali memperhitungkan biaya-biaya yang dikeluarkan secara terperinci. Selain itu mereka juga jarang mencatat berapa penerimaan yang diperoleh, besarnya biaya dan penerimaan petani dari usahatani yang sebenarnya mereka terima sulit untuk diketahui bahkan belum pernah menghitung besarnya $\mathrm{R} / \mathrm{C}$ dari usahataninya sehingga mereka tidak mengetahui apakah layak atau tidaknya usahatani cabai merah tersebut (Ratnawati, et al, 2019). Berdasarkan uraian tersebut, maka dilakukan penelitian mengenai Analisis Keuntungan dan Sensitivitas Usahatani Cabai Di Kabupaten Maros.

\section{METODE PENELITIAN}

\section{Waktu dan Tempat}

Penelitian dilakukan di Kecamatan Tanralili, Kabupaten Maros, Sulawesi Selatan pada bulan Februari sampai Juni 2017. Penentuan lokasi kajian ini didasari pertimbangan bahwa lokasi tersebut merupakan wilayah pengembangan cabai.

\section{Data dan Analisis Data}

Penelitian ini menggunakan data primer yang dikumpulan dari petani cabai sebanyak 60 responden dengan menggunakan kuisioner terstruktur. Data yang terkumpul dianalisis secara deskriptif tabulatif. Analisis finansial dilakukan untuk mengetahui keuntungan usahatani cabai, titik impas dan sensitivitas dari usahatan cabai. Usahatani dianggap layak, jika R/C lebih dari satu. Formulasi dari R/C adalah (Kasijadi dan Suwono, 2001):

$$
\mathrm{R} / \mathrm{C}=\frac{\mathrm{P} \times \mathrm{Q}}{\mathrm{Bi}}
$$

dimana :

$\mathrm{P} \quad=$ harga produksi $(\mathrm{Rp} / \mathrm{Kg})$

$\mathrm{Q} \quad=$ hasil produksi $(\mathrm{Kg} / \mathrm{ha})$

$\mathrm{Bi} \quad=$ Biaya produksi ke I $(\mathrm{Rp} / \mathrm{ha})$

Analisis titik impas digunakan untuk mentolerir penurunan produksi atau harga produk sampai batas tertentu dimana usaha yang dilakukan masih memberikan tingkat keuntungan normal. Nilai titik impas produksi (TIP) dan titik impas harga (TIH) dihitung dengan rumus (Rahmanto dan Adnyana, 1997) :

$\mathrm{BEP}$ produksi $=\mathrm{BP} / \mathrm{H}$ dan $\mathrm{BEP}$ harga $=\mathrm{BP} / \mathrm{P}$

Keterangan:

$\mathrm{P}=$ Produksi $(\mathrm{Kg})$

$\mathrm{H}=$ Harga produksi $(\mathrm{Rp} / \mathrm{Kg})$

$\mathrm{BP}=$ Biaya produksi (Biaya tetap dan variabel)

Analisis dilanjutkan untuk melihat kepekaan atau sensitivitas usahatani cabai bila terjadi perubahan dalam perhitungan biaya atau keuntungan. Dalam analisis ini akan ditentukan pada tingkat perubahan harga dengan berbagai pendekatan dan asumsi, baik secara parsial maupun secara simultan yang mendekati kenyataan lapang. Analisis senstivitas dilihat dengan 3 skenario yaitu 1) Harga produksi turun $30 \%$; 2) Biaya naik $30 \%$; dan 3) Produksi turun $30 \%$.

\section{HASIL DAN PEMBAHASAN}

\section{Karakteristik wilayah}

Secara geografis kecamatan Tanralili yang terletak di Kabupaten Maros merupakan daerah bukan pantai yang sebagian besar berbentuk dataran. Dari delapan daerah wilayah administrasi yang ada, mempunyai topografi dataran daerah dengan ketinggian rata-rata lima ratus meter diatas permukaan laut.

Kecamatan ini terbagi atas delapan Desa/Kelurahan yaitu Desa Purna Karya, Desa Leko Pancing, Desa Kurusumange, Desa Sudirman, Desa Damai, Desa Allaere, Desa Borong dan Kelurahan Toddopulia. Luas Kecamatan Tanralili sekitar $89,46 \mathrm{~km}^{2}$ sebelah barat berbatasan dengan Kecamatan Mandai, sebelah timur berbatasan dengan kecamatan Bantimurung, 
sebelah utara berbatasan dengan kecamatan Simbang dan sebelah selatan berbatasan dengan kecamatan Tompobulu. Jarak antara desa dengan pusat pemerintahan kabupaten cukup dekat yaitu rata-rata $8 \mathrm{Km}$ (BPS Maros, 2019).

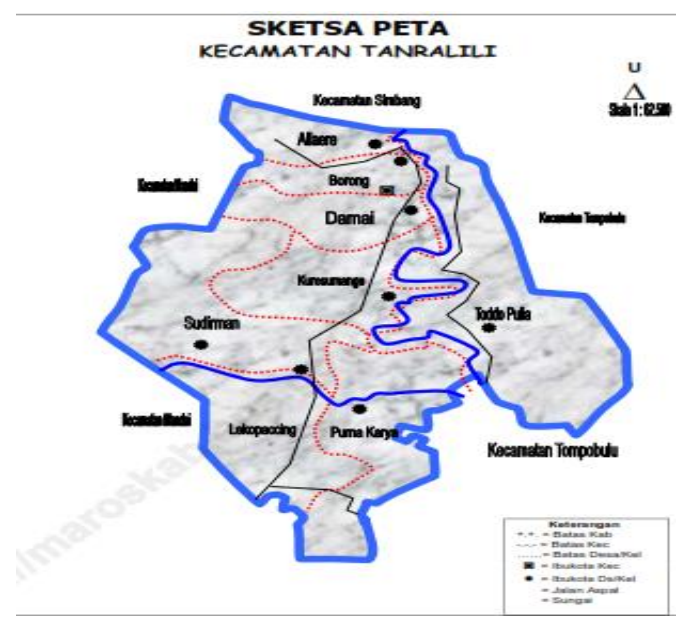

Berdasarkan banyaknya curah hujan di Kabupaten Maros dapat dibagi beberapa Zone Iklim menurut Oldeman. Dari kriteria yang dikemukakan oleh Oldeman tersebut, maka iklim daerah wilayah
Kabupaten Maros memiliki type iklim B2, C2 , C3 , D2 dan E2. Type iklim B2, dengan jumlah bulan basah 7 - 9 bulan dan bulan kering 2 - 4 bulan terdapat sebagian besar di Kecamatan Tanralili dan sebagaian kecil di bagian Selatan Kecamatan Camba . Type iklim C2 dengan jumlah bulan basah $5-6$ bulan dan bulan kering 2 - 3 bulan tersebar dibagian Barat Kecamatan Tanralili, sebagian besar di Bantimurung, Camba dan Mallawa.

\section{Karakteristik Responden}

Karakteristik responden merupakan salah satu aspek penting yang berpengaruh dalam mengadopsi inovasi dalam usahatani. Karakteristik digambarkan oleh umur, tingkat pendidikan, luas lahan usahatani, status pemilikan lahan, sumber informasi yang digunakan, dan tingkat hidup seseorang. Menurut Far-Far (2011), karakteristik individu merupakan salah satu faktor penting untuk diketahui dalam rangka mengetahui kecenderungan perilaku seseorang atau masyarakat dalam kehidupannya. Deskripsi karakteristik responden berdasarkan hasil penelitian dapat dilihat pada tabel 1 .

Tabel 1. Karaktersitik responden pada usahatani cabai di Kab. Maros.

\begin{tabular}{cc}
\hline Umur Petani & Persentase \\
\hline$<30$ thn & 15.29 \\
$30-54$ thn & 77.65 \\
$\geq 55$ thn & 7.06 \\
\hline Pendidikan Formal & Persentase \\
SD & 17.86 \\
SMP & 32.14 \\
SMU & 41.67 \\
S1 & 8.33 \\
\hline S-10 tahun & Persentase \\
$11-15$ tahun & 74.12 \\
$>15$ tahun & 20 \\
\hline Pengalaman Berusahatani (thn) & 5.88 \\
\hline Kepemilikan Lahan (Ha) & Persentase \\
\hline $0.5-2$ & 96.47 \\
$>2$ & 3.53 \\
\hline Klasifikasi Tanggungan Keluarga (orang) & 0 \\
\hline $0-3$ & Persentase \\
$4-7$ & 68.24 \\
7 & 21.18 \\
\hline
\end{tabular}

Diterbitkan Oleh, 
Berdasarkan penggolongan umur produktif, sebagian besar petani responden tergolong umur produktif dimana merupakan usia ideal untuk bekerja dan mempunyai kemampuan untuk meningkatkan produktivitas kerja serta memiliki kemampuan yang besar dalam menyerap informasi dan teknologi yang inovatif di bidang pertanian. Petani yang berumur lebih muda biasanya lebih bersemangat dibandingkan dengan petani yang lebih tua. Semakin tua (di atas 50 tahun), biasanya semakin lamban mengadopsi inovasi dan cenderung hanya melaksanakan kegiatan-kegiatan yang sudah diterapkan oleh warga masyarakat setempat (Mardikanto, 2009). Sayektiningsih, et al (2014), menyatakan rentang usia 30-50 tahun merupakan rentang usia produktif, di mana mereka dapat berkarya dan bekerja secara optimal. Umumnya, responden dengan usia tersebut berkewajiban memenuhi kebutuhan hidup sehari-hari dengan bekerja antara lain di bidang pertanian, sebaliknya bertambahnya usia dapat berpengaruh pada pertambahan pengetahuan yang diperolehnya, dan pada usia tertentu atau menjelang usia lanjut kemampuan penerimaan atau mengingat suatu pengetahuan akan berkurang (Ahmadi, 2001).

Tingkat pendidikan seseorang akan mempengaruhi kreativitas dan kemampuan seseorang dalam menerima inovasi baru, serta berpengaruh terhadap perilaku petani dalam mengelola kegiatan usahataninya. Makin meningkat pendidikan seseorang, maka kualitas kerjanya juga meningkat (Syahyuti, 2006). sebagian besar petani responden memiliki tingkat pendidikan SMU yaitu sebanyak 41,67\%, berpendidikan SMP sebanyak 32,14\%, berpendidikan SD sebanyak $17,86 \%$ dan yang berpendidikan sarjana sebanyak $8,33 \%$, sehingga memberikan gambaran kapasitas yang cukup mendukung dalam mengakses informasi teknologi. Petani yang memiliki tingkat pendidikan yang lebih tinggi memiliki kemampuan yang lebih baik dalam memahami dan menerapkan teknologi sehingga produktivitasnya menjadi lebih tinggi. Sulistiyono, et al., (2008) menunjukkan bahwa pengetahuan petani semakin tinggi kategorinya sesuai dengan jenjang pendidikannya.
Pengalaman berusahatani merupakan penggambaran tingkat keterampilan teknis yang dimiliki, pemikiran rasional dan kemampuan untuk melakukan inovasi usahatani yang dapat memberikan nilai tambah. sebagian besar petani memiliki pengalaman berusahatani cabai yang sudah cukup banyak yaitu 5-10 tahun sebesar $74,12 \%$, aspek pengalaman berusahatani menurut Rukka, et al., (2006) bahwa pengalaman petani dalam berusahatani berpengaruh terhadap cara merespon suatu inovasi. Semakin lama pengalaman berusahatani, maka tingkat respon terhadap suatu teknologi akan semakin tinggi.

Luas lahan yang dimiliki sebagian besar petani adalah lahan sempit, menurut Sudaryanto et al. (2009) ukuran usahatani tidak menjadi masalah pada tataran implementasi usahatani. Permasalahan sempitnya penguasaan lahan usahatani lebih pada aspek pemenuhan kebutuhan rumah tangga dari hasil usahatani. Usahatani lahan sempit, meskipun dilakukan secara intensif tetap tidak akan dapat memenuhi kebutuhan rumah tangga sehingga perlu upaya tambahan pendapatan dari sumber lain.

Tanggungan keluarga merupakan salah satu sumberdaya manusia pertanian yang dimilik oleh petani, terutama yang berusia produktif dan ikut membantu dalam usahataninya. Sebagian besar petani mempunyai tanggungan keluarga yang kecil yaitu sebanyak 58 orang atau 68,24\%. Tanggungan keluarga merupakan salah satu sumberdaya manusia pertanian yang dimilik oleh petani, terutama yang berusia produktif dan ikut membanu dalam usahataninya. Tanggungan keluarga juga dapat menjadi beban hidup bagi keluarganya apabila tidak aktif bekerja (Syafrudin, 2003).

\section{Analisis Keuntungan dan Sensitivitas Usahatani Cabai}

Pelaksanaan usahatani cabai tidak lepas dari biaya, penerimaan, dan pendapatan. Semua nilai input produksi selama proses berlangsung akan di hitung secara terperinci. Setiap kegiatan usahatani pada akhirnya akan dinilai hasil yang akan diperoleh dari biaya yang dikeluarkan selama proses produksi berlangsung. Usahatani yang dilakukan oleh petani responden dapat dilihat pada Tabel 2.

Diterbitkan Oleh, 
Tabel 2. Analisis usahatantani cabai di Kab. Maros

\begin{tabular}{clr}
\hline No. & \multicolumn{1}{c}{ Keterangan } & Jumlah \\
\hline 1 & Rata-rata Jumlah Panen (kali) & 13 \\
2 & Rata-rata Harga Cabai per Kg (Rp) & 70000 \\
3 & Rata-rata Jumlah Produksi (Kg) & 1532 \\
4 & Rata-rata Biaya Produksi (Rp) & 5596482 \\
5 & Pendapatan Usahatani (Rp) & 107240000 \\
6 & Keuntungan Usahatani (Rp) & 101643518 \\
7 & R/C Ratio & 19.16 \\
8 & BEP Produksi & 79.95 \\
9 & BEP Harga & 3653 \\
\hline
\end{tabular}

Usahatani yang dilakukan oleh petani responden mendapatkan keuntungan yang cukup tinggi serta usahatani tersebut layak dilanjutkan karena keuntungan yang diperoleh mencapai $\mathrm{Rp}$. 101.643.518 dengan nilai $\mathrm{R} / \mathrm{C}$ ratio 19,16 nilai $\mathrm{R} / \mathrm{C}$ tersebut $>1$, yang berarti usahatani tersebut layak untuk diusahakan dan dikembangkan (Soekartawi, 2002). Tujuan akhir dari usahatani adalah memperoleh pendapatan dan keuntungan semaksimal mungkin dari proses usahatani yang dilakukan, Rahim dan Hastuti (2007), menyatakan petani mengusahakan usahataninya bertujuan untuk mendapatkan keuntungan yang maksimal sehingga dapat mengimbangi pengeluaran biayabiaya yang dikeluarkan selama proses produksi.

Harga cabai yang tinggi dipasaran memberi keuntungan kepada petani, akan tetapi harga tersebut berfluktuasi tidak selamanya menguntungkan petani, disaat permintaan yang banyak dan persediaan sedikit maka saat itulah harga cabai menjadi tinggi sebaliknya jika persediaan cabai cukup banyak seperti banyak daerah yang panen cabai maka harga cabai akan sangat murah, disamping itu produk pertanian adalah produk yang cepat rusak biasanya petani menjualnya secara langsung, tidak melalui proses pasca panen yang sudah dianjurkan oleh penyuluh dengan tujuan untuk mempertahankan harga dan meningkatkan nilai produk pertanian.

\section{Analisis Sensitivitas Usahatani Cabai}

Analisis sensitivitas berguna untuk mengetahui kepekaan efisiensi finansial dan ekonomi dalam usahatani cabai. Hasil analisis pada Tabel 3 menunjukkan bahwa berbagai skenario perubahan harga produksi dan jumlah produksi , maupun kenaikan biaya produksi usahatani cabai masih memberikan keuntungan yang memadai walaupun tingkat keuntungan cenderung menurun. Data analisis sensitivitas usahatani cabai disajikan pada Tabel 3.

Tabel 3. Analisis sensitivitas usahatani cabai di Kab. Maros

\begin{tabular}{|c|c|c|c|c|}
\hline No. & Keterangan & $\begin{array}{c}\text { Harga Produksi } \\
\text { Turun } 30 \% \\
\end{array}$ & Biaya Naik $30 \%$ & $\begin{array}{c}\text { Produksi Turun } \\
30 \% \\
\end{array}$ \\
\hline 1 & Rata-rata Harga Cabai per Kg (Rp) & 49000 & 70000 & 70000 \\
\hline 2 & Rata-rata Jumlah Produksi (Kg) & 1532 & 1532 & 1072 \\
\hline 3 & Rata-rata Biaya Produksi (Rp) & 5596482 & 7275426.6 & 5596482 \\
\hline 4 & Pendapatan Usahatani (Rp) & 75068000 & 107240000 & 75068000 \\
\hline 5 & Keuntungan Usahatani (Rp) & 69471518 & 99964573.4 & 69471518 \\
\hline 6 & R/C Ratio & 13.41 & 14.74 & 13.41 \\
\hline
\end{tabular}

Diterbitkan Oleh, 
Berdasarkan kondisi tersebut dapat dikatakan bahwa usahatani jagung di daerah penelitian tidak sensitiv atau tidak peka terhadap perubahan harga. Suatu usahatani dikatakan peka apabila dengan adanya sedikit penurunan harga atau produksi menyebabkan kerugian, sebaliknya tidak peka apabila terjadi sedikit penurunan harga dan produksi tidak menyebabkan usahatani tersebut rugi.

\section{KESIMPULAN}

1. Usahatani Cabai di Kab. Maros secara financial menguntungkan sebesar

Rp. 101.643.518 dengan nilai R/C 19,6. Sehingga usahatani tersebut dikatakan sangat layak untuk dilakukan

2. Dengan menggunakan analisis BEP produksi dan BEP harga produksi dan harga minimum yang harus dicapai agar usahatani cabai tetap menguntungkan adalah 79,95 kg/ha dan Rp. $3653 / \mathrm{kg}$.

3. Penurunan harga dan produksi serta peningkatan biaya produksi masih memberikan keuntungan walaupun cenderung menurun. Sehingga usahatani cabai tersebut dikatakan tidak peka atau sensitive terhadap penurunan harga serta produksi serta peningkatan biaya produksi.

\section{DAFTAR PUSTAKA}

Ahmadi, A. 2001. Psikologi Sosial. Jakarta : Rineka Cipta.

Far-Far R. 2011. Hubungan komunikasi interpersonal dengan perilaku petani dalam bercocok tanam padi sawah di Desa Waimital Kabupaten Seram Bagian Barat. J Budid Pertan. 7(2):100-106.

Kasijadi, F. dan Suwono. 2003. Penerapan rakitan penerapan teknologi dalam peningkatan daya saing usahatani padi di Jawa Timur. Jurnal Pengkajian dan Pengembangan Teknologi Pertanian Vol. 6, No. 2 : 117130.

Mardikanto, T. 2009. Sistem Penyuluhan Pertanian. Uns Press :Surakarta.

Rukka H., Buhaerah dan Sunaryo. 2006. Hubungan Karakteristik Petani dengan Respon Petani terhadap Penggunaan Pupuk
Organik pada Padi sawah (Oryza sativa L.). Jurnal Agrisistem, 2(1):12-18.

Rahim, Abdul dan Diah Retno Dwi Hastuti. 2007. Ekonomika Pertanian (Pengantar, Teori dan Kasus). Jakarta: Salemba Empat.

Ratnawati, I., Trisna, I.N., Dani, L.H. 2019. Analisis Kelayakan Usahatani Cabai Merah (Studi Kasus pada Kelompok Tani Mekar Subur Desa Maparah Kecamatan Panjalu Kabupaten Ciamis). Jurnal Ilmiah Mahasiswa AGROINFO GALUH Volume 6, Nomor 2, Mei 2019: 422-429.

Rizqullah, M.R dan Syamsuddin, T. 2020. Analisis Pendapatan Usahatani Cabai Merah DI Desa Talang Kemang Kecamatan Rantau Bayur Kabupaten Banyuasin Sumatera Selatan. Jurnal Ilmu Pertanian Agonitas Vol. 2 No.1 : 54-62.

Syafrudin. 2003. Pengaruh Media Cetak Brosur Dalam Proses Adopsi dan Difusi Inovasi Beternak Ayam Broiler di kota Kediri. Diakses tanggal 24 oktober 2020. http://repository.usu.ac.id..

Syahyuti. 2006. 30 Konsep Penting dalam Pembangunan Pedesaan dan Pertanian. Bina Rena Pariwara : Jakarta.

Sulistiyono L,. Tarumingkeng R.C., Sanim B., dan Dadang. 2008. Pengetahuan, Sikap dan Tindakan Petani Bawang Merah dalam PenggunaanPestisida (Studi Kasus di KabupatenNganjuk Propinsi Jawa Timur). Jurnal Agroland,15(01):12-17.

Sayektiningsih T., Atmoko T., \& Ma'ruf, A. 2014. Persepsi Masyarakat Terhadap Pembangunan Penangkaran Rusa Sambar (Cervus Unicolor Kerr, 1792) Di Khdtk Samboja, Kalimantan Timur (The Community's Perception On Sambar Deer (Cervus Unicolor Kerr, 1792) Captive Breeding Establishment In Forest Area In Special Purposes (Fasp) Samboja, East Kalimantan). Jurnal Penelitian hutan dan Konservasi Alam, 11(2):143-153.

Soekartawi. 2002. Analisis Usahatani. Universitas Indonesia (UI-press) : Jakarta.

Diterbitkan Oleh, 